\title{
DIE ONVERGEEFLIKE SONDE
}

\section{Inleiding.}

Daar is ' $n$ besondere groep van die Nieu-Testamentiese uitsprake wat handel oor die onvergeeflike sonde, en waarin teen hierdie onherroepelike sonde gewaarsku word. Soos hegryp kan word, was hierdie uitsprake oor die onvergeeflike sonde die aanleiding tot onnoembare angs en foltering en benoudheid vir menige gelowige deur die eeue. En seker elke predikant word in sy pastorale dienswerk in die kerk meermale gestel voor die vrae oor wat die onvergeeflike sonde, of die lastering teen die Heilige Gees werklik is. En hierdie vrae word meesal nie gebore uit spekulatiewe of teologiese belangstelling nie, mar uit felle geestelike nood en vertwyfeling en dit meesal juis by toegewyde gelowiges. Dit gaan dus by die ondersoek van hierdie bepaalde Skrifuitsprake om meer as net teologiese belangstelling. Met die verklaring van genoemde uitsprake word ons enersyds met allerlei moeilike probleme gekonfrunteer; andersyds verteenwoordig die groep tekste 'n saak wat van groot pastorale belang is. Hoe moct ons hierdie saak benader?

So fel en intens as die stryd en vertwyfeling kan wees oor hierdie vraag, net so intens ook die teleurstelling as die pastor nie toegerus is om die hulp en troos van Gods Woord te bied nie.

Maar andersyds mag ons ook nie uit pastorale bewogenheid en mede. lye met hulle wat in angs en vertwyfeling worstel met hierdie probleem die ontsaglike erns van hierdie Skrifwoorde gaan verdoesel of verswak nie. Dic woorde van Jesus bv. in Mark 3:29 is te duidelik en nadruklik as om te beskou dat hulle maar hiperbolies gebruik is. Ook elders merk ons die nadruklike klank van ernstige waarskuwing in Jesus se woorde, soos bv. in Mark. $9: 42,48$; Matt. 25:41-46.

Vir 'n gelowige wat voor die dieptes van angs, en vertwyfeling staan, - 'n vertwyfeling wat juis ontstaan het uit hierdie Bybeluitsprake, vir 'n gelowige wat dan nog verder deur die duiwel verskrik word met die gedagte dat hy die sonde teen die Heilige Gees begaan het, die sonde wat nooit vergewe kan word nie, en dat die genade van God vir hom niks meer kan doen nie, - - vir so iemand bied die welmenende gerusstellinge en menslike argumente en wanhopige bokspronge van 'n in-die-hoek-gejaagde sielsorger nie die sekerheid en rus waarna hy soek nie. Ook hier is van toepassing dat alleen die waarheid ons vry maak, dié waarheid van Gods Woord. En dit beteken, ock in hierdie geval dat ons moet begin om die betrokke skrifgedeeltes ernsiig en rustig en biddend te eksegetiseer. Eers daarna, cers nadat ons oor die inhoud en betekenis van hierdie betrokke Skrifgedeeltes tot sekerheid gekom het, kan ons met vertroue gaan spreek met diegenes wat bekommerd is, of reeds 
deur vrees oorweldig is, dat hulle hierdie onherroepelike sonde begaan het. Dit kan bv: veel beteken as 'n predikant, opgrond van 'n deeglike studie van die betrokke Skrifgedeeltes die stellige versekering kan gee dat elkeen wat nog bekommerd of bevrees is dat hy of sy teen die Heilige Gees gelaster het, in daardie kommer en vrees juis die versekering mag sien dat hy of sy die onvergeeflike sonde nog nie begaan het nie. Eers as hierdic vrees wat die denke en verstaan verwar en benewel, verwyder is, kan daar rustig en vrugbaar oor hierdie Skrifuitsprake gespreek word en oor die ernstige waarskuwing wat inderdaad daarin vervat is. En met so'n gesprek sal mens wel met twee dinge rekening moet hou : eerstens om iemand wat bekommerd is oor sy sonde en daarin verstrik en gefolter word deur die gedagte dat hy miskien al die onvergeeflike sonde begaan het, en wat daarin verder deur die Satan verskrik word, te hulp te snel met geen ander middel nie, as om hom te help om die betrokke Skrifgedeeltes reg te verstaan. Andersyds mag ons nie probeer om met welmenende menslike barmhartigheid die groot erns van die betrokke Skrif. woorde te verswak, en om die afgrond van hierdie onherroepelike sonde te versluier en te hedek, wat God juis waarskuwend wil laat sien nic. Waar 'n mens barmhartiger as God wil wees, loop dit uit op 'n ontsettende onbarmhartigheid. ${ }^{1}$ )

\section{Beperking van Ondersoek.}

Hoewel die Nuwe Testament veel meer uitsprake bevat wat met bogenoemde saak in verband staan, wil ons hierdie ondersoek beperk tot enkele tekste, en hulle betekenis nagaan wat hulle het in dié ver bande waarin hulle voorkom.

Ten eerste is daar enkele uitsprake in die Sinopticse Evangelies, warin ons met woorde van Jesus self te doen het, en waarmee ons moet begin. Dit is nl. Mark. 3:28, 29; Matt. 12:31. 32 en Luk. 12:10. Uit die Brief aan die Hebreërs gee ons besondere aandag aan twee Skrifgedeeltes, nl. Hebr. 4:4.8 en Hebr. 10:26-19, maar dan ook I Joh. 5:16 waarin gespreek van die sonde tot die dood, hamartia pros thanaton. Vir iemand wat hierdie sonde begaan het, sê die apustel dat 'n mens nie moet bid nie.

\section{Eksegese.}

\section{a. Die uitspraak in die Sinoptese Evangelies.}

In die genoemde uitsprake van Sinoptiese Evangelies gaan dit oor die lastering of 'n spreek teen die Heilige Gees. Om 'n duidelike heeld

1) Vgl. Joh. Calvin: Commentaries on the Catholic Epistles, translated and edited by John 0wen, Michigan, 1948. p. 270 waar Calvyn na aanleiding van I Joh. 5:16 oor die sonde tot die dood sê: „But if the impiety appears to us not otherwise than hopeless, as though the Lord pointed it out by the finger, we ought not to contend with the just judgmeni of God, or seek to be more merciful than He is". 
tc kry van die woorde waarom dit hier gaan, haal ons hierdie teksie in die bepaalde volgorde aan, Vulgens Mark. $3: 28$, 29 het Jesus gesê : Voorwaar Ek sê vir julle, al die sonde sal die mensekinders vergewe word, en al die lasteringe wat hulle mag uitgespreek het; maar wie teen die Heilige Gees gelaster het, het geen vergifnis tot in ewigheid nie, maar is skuldig aan die ewige sonde, ${ }^{2}$ ) - omdat hulle gesê het : Hy het 'n onreine gees. Volgens Matt. 12:31, 32 was Jesus sc woorde : Daarom sê Ek vir julle : Elke sonde en lastering sal die mense vergewe word, maar die lastering teen die Gees sal die mense nie vergewe word nie. En clkeen wat 'n wourd spreek teen die Seun van die mens, dit sal hom ver. gewe word; maar elkeen wat spreck teen dic Heilige Gees, dit sal hom nie vergewe word nie, nie in hierdie eeu nie, ook nie in die toekomende nie. Waar hier in Matt. 12:31, 32 verskillende voorstellinge aanwesig is, is dic voorstelling enkelvoudig in Luk. 12:10 waar ons lees : En elkeen wat $n$ woord teen die Seun van die mens sal spreek, dit sal hom vergewe word; maar vir hom wat gelaster het teen die Heilige Gees, sal dit nie vergewe word nie.

In die genoemde tekste het ons twee voorstellinge naas mekaar oor die spreek of lastering teen die Heilige Gees, en dis moeilik om die ontstaan van hierdie twce voorstellinge te verklaar, soos ons dit enersyds vind in Mark. $3: 28,29$ en Matt. 12:31, - en andersyds in Matt. $12: 32$ en Luk. $12: 10$. Want enersyds word in Mark. 3:28, 29 en Matt. 12:31 die lastering teen die Heilige Gees gestel teenoor al dic ander lasteringe en sondes, en word gesê dat elke sonde en lastering wat die monsekinders mag hegaan vir hulle vergewe sal word, maar wie teen dic Heilige Gees gelaster het, het geen vergifnis nie, maar is skuldig aan die ewige sonde. Hier in Mark. 3:28, 29 en Matt. 12:31 word die lastcring teen die Heilige Gees teenoor al die ander lasteringe en sondes dus gestel as die enigste onvergeeflike sonde, en dit word hier genoem in verband met dic wonder van die demone-uitbanning deur Jesus, wat deur die Fariseërs duiwelswerk genoem word. Die geskiedenis van die genesing van die duiwelbesetene deur Jesus, soos dit verhaal word in Matt. $12: 22$ vv., verteenwoordig waarskynlik die historiese grondslag van Jesus se woorde. Jesus se woorde oor die sonde teen die Heilige

2) In navolging van die Textus Receptus vertaal die Afrikaanse Bybel: maar is skuldig aan die ewige oordeel. Hierdie vertaling vind steun in verskillende handskrifte soos A. C. wat kriseós lees, asook in ou vertalinge soos die Vulgaat en die Siriese Bybelrewisie van die Peschitta deur Biskop Rabbula van Edessa en die rewisie van Thomas van Charkel, 616 n.Chr. Cranfield, The Gospel according to St. Mark, 1950 oorweeg ook die moontlikheid op bl. 141 v. dat hamartéma 'n verkeerde vertaling kan wees van 'n Aramese woord wat met katakrima vertaal moes word, en wys daarop dat die Aramese woord hub kan beteken: "sondig" en "veroordeel". Die Nederlandse vertalinge van Prof. A. M. Brouwer. Petrus Canisius, die Leidse Vertaling asook die nuwe vertaling van die N.B.G. lees almal: eeuwige zonde, vgl. Het Nieuwe Testament in Zes Nederlandse Vertalingen, Amsterdam 1950. 
Gees moet hier gesien word in verband met die woorde van dic Fariseërs: Hy dryf die duiwels nie anders uit as deur Beëlsebul, die owerste van die duiwels nie, Matt. $12: 24$.

Maar naas bogenoemde voorstelling staan 'n tweede. En hierdie tweede voorstelling is vervat in Matt. $12: 32$ en Luk. 12:10. In hierdie tekste word daar nie gepraat oor 'n lastering van die Heilige Gees in verband met die lastering van die Fariseërs oor Jesus se uitbanning van die demone nie, ook nie oor elke ander lastering of sonde wat die mensekinders mag begaan ne, - maar hier word teenoor mekaar gestel : 'n spreek teen die Seun van die mens sal vergewe word, maar vir hom wat teen die Heilige Gees gelaster het, sal dit nie vergewe word nie. Beide hierdie voorstellinge wat in die Sinoptiese Evangelis aanwesig is, nl. in Mark. 3:28, $29 \mathrm{cn}$ Matt. 12:31 enersyds, en in Matt. 12:32 en Luk. 12:10 andersyds, word deur die Evangelis Mattheus in sy Evangelie naismekaar gestel en so saamgevoeg in Matt. 12:31, 32 .

Maar nou staan ons nog voor die vraag hoe hierdie twee voorstellinge oor die lastering teen dié Heilige Gees in die Sinoptiese Evangelies verstaan moet word. Die verklaring van hierdie uitsprake lewer allerlei probleme op.

(i) Mark $3: 28,29$; Matt. $12: 31$.

Dit is vir die verklaring van besondere belang om op te merk dat die voorstelling, soos dit uitgespreek is in Mark. 3:28, 29 en Matt. $12: 31$ die historiese grondslag van Jesus se woorde verteenwoordig, en in verband staan met die lastering van die Fariseërs, as gevolg van dic uitdrywing van die demone deur Jesus. Hulle het gesê : Deur die Jwerste van die duiwels dryf $\mathrm{Hy}$ die duiwels uit, Mark. $3: 22$, Die uitspraak van Markus oor die lastering teen die Heilige Gees pas dus in hierdic historiese verband waarin hy dit plaas, óók deur die woorde van Mark. $3: 30$ : omdat hulle gesê het : $\mathrm{Hy}$ het 'n onreine gees.

Waarin bestaan nou in hierdie verband die lastering teen die Heilige Gees? As antwoord op hierdie vraag moet ons daarop wys dat Jesus reeds by sy doop toegerus is met die krag van die Heilige Gces om as Messias die koningsheerskappy van God te bring en om die ryk van die duiwel te verstoor. As Jesus die demone verdryf en mense verlos uit hulle mag, as Jesus die Satan soos 'n bliksemstraal van die hemel sien aftuimel, (Luk. 10:28), dan is dit ' $n$ duidelike bewys dat Jesus besig is om met die krag van die Heilige Gees die ryk van die duiwel te verdring en te vernietig, en die heerskappy van God te bring. Daarom kon Jesus ook sê, volgens Matt. 12:18: Maar as Ek deur die Gees van God die demone uitwerp, dan het die koninkryk van God by julle gekom. Maar wie nou hierdie werk wat in die krag van Gods Gees verrig word, duiwelswerk noem, maak hom skuldig aan godslastering, blasphemia, hy tas die heiligheid en majesteit van God aan. Die werk wat Jesus in die 
krag wan die Gees doen, die werk van die Heilige Gees self, nuem die Fariseërs duiwelswerk. Hierdie duidelike werk van Gods Gees skryf hulle aan die duiwel toe, -- on daarmee sataniseer hulle a.h.w. God self. Hulle assosieër die werk van die Heilige Gees met 'n onreine gees, omdat hulle gesê het : $\mathrm{Hy}$ het 'n onreine Gees, Mark. 3:30. Sulke mense wat hullesclf so bewustelik en opsetlik teen die werk van God stel, het geen vergifnis tot in ewigheid nie, maar is skuldig aan die ewige sonde, hamartéma, Mark $3: 29$.

Volgens Matt. $12: 22$ vv. was die duiwelbesetene wat Jesus uit die duistere magte gered het, blind en stom. Toe Jesus hom genees het, kon die blinde en stomme sien en prat. Met verbasing vra die skare: Is $\mathrm{Hy}$ nie miskien die Seun van Dawid nie? Hulle oorweeg dit of $\mathrm{Hy}$ nie die Messias is nie. Dit kan wees dat hulle gedink het aan die groot dade wat in die Messiasryk beloof is in Jes. 35:5, 6: Dan sal die oë van die blindes geopen word, en die ore van die dowes ontsluit word... . en die tong van die stomme sal jubel. Selfs die menigtes is verbaas, en oorweeg die moontlikheid van 'n Messiaswonder, wat hier verrig is in die krag van die Gees. Maar die Skrifgeleerdes wat volgens Mark. 3:22 van Jerusalem af kom, (volgens Matt. 12:24 was dit Fariseërs) -- wat dus baie beter behoort te weet as die skares, - hulle skryf hierdie duidelike werk van die Gees aan dic duiwel toe. Hier word nie in dwaling of uit onkunde gesondig nie, maar hier word bewus en opsetlik die werk van Gods Gees weerstaan. En dit kom hierop neer dat hulle opsetlik, hekousiós, bejád rámá, vgl. Num. $15: 30$ die genadige en verlossende werk van Christus deur die Heilige Gees toeskryf aan die Satan. En vir wie só sondig, met opgehewe hand, is daar geen vergifnis nie, maar hy is skuldig aan die ewige sonde enochos estin aióniou hamartematos. Die ongewone uitdrukking : ewige sonde kan 'n sonde aandui wat so ernstig is, dat dit ewige gevolge het.

Volgens Mark. 3:30 het Jesus die woorde oor dic lastering teen die Heilige Gees uitgespreek, omdat die Skrifgeleerdes gesê het : Hy het in onrcine gees. Die duratiewe Imperfektum elegon in Mark. $3: 22,30$ wys tenminste op 'n herhaling van wat die Skrifgeleerdes gesê het : hulle het volgehou om te sê. Die lastering teen die Heilige Gees word dus nie begaan deur die eenmalige uitspreek van woorde of 'n vloek. formule teen die Heilige Gees nie, ${ }^{3}$ ) of deur in eenmalige daad nie, maar deur 'n volhardende gesindheid van vyandskap en weerstand teen die werk van Gods Gees. Die sunde teen die Heilige Gees kan nie in unwetenheid begaan word nie, soos bv. wanneer mens op 'n ongelukkige oomblik in 'n onsigbare sonderstrik trap, wat onherroepelik die ewige

3) Vgl. G. Kittel - G. Friedrich, Theologisch's Wörterbuch zum Neuen Testament, Thwb. I, 623 oor blasphémia. 
ongeluk en veroordeling meerbring nie. Maar dis die bewuste afwysing van die redding en genade van God; dis die stel van die sondige wil teen die heilige duidelik-geopenbaarde reddende liefdewil van die Heilige Gees; dit is uittarting van die Gees, wat ook die onaantasbaar-Heilige is. In hierdie uitsprake oor die lastering teen die Heilige Gees, wat onvergeeflik is, word die Heilige Gees gesien as die heilige Wil, na die momente van sy ywer en energicum en sy onaantasbaarheid, die heilige Wil wat gehoorsaamheid verlang, en wat nie verdra om uitgetart en moeds. willig weerstaan te word nie. ${ }^{4}$ ).

Die vraag kan gestel word, watter verskil daar is enersyds tussen die Skrifgeleerdes uit Jerusalem wat Jesus se stryd teen die demone is die krag van die Gees duiwelswerk noem, en andersyds sy familie wat Hom wou gaan vang, omdat hulle gemeen het dat $\mathrm{Hy}$ buite sy sinne is, Mark. $3: 21$, 22. Die verskil kan hierin lê dat die Skrifgeleerdes die deskundiges was op die gebied van godsdiens en kerk. Hulle was daagliks besig met die Woord van God, en daarom ook met die Heilige Gees. wat as die Gees van die profetiese inspirasie elke dag met hulle spreek in die woorde van die Skrif, - terwyl die familie van Jesus eenvoudige, gewone mense was. Jesus se familie kon nog in dwaling of onwetenheid sondig, en vir sulke sondes is daar vergifnis moontlik, vgl. Num. $15: 26$ : bishegágá, terwyl die deskundiges, as hulle teen die Heilige Gees sondig. dit moet doen met opgehewe hand, bejád rámá, Num. 15:30. Sơn moedswillige, opsetlike sonde kan nie vergewe word nie. En met hierdie voorstelling het Jesus dan aangesluit by die Ou Testament wat reeds onderskei het tussen die sonde wat in swakheid, in dwaling of vergissing begaan word, vgl. Num. $15: 28$ en waarvoor daar vergifnis is, en andersyds die sunde wat met opgehewe hand, moedswillig en opsetlik teen God begaan word, en wat nie vergewe kan word nie, Num. 15:30 Iemand wat so sondig ,het die Here versmaad" ... . en "die siel moct uitgeroei word onder sy volk uit", Die vuur van hierdie ywer vir die heiligheid van God gloei nog na in die Nuwe Testament in hierdie uitsprake oor die lastering teen die Heilige Gees, en in sulke woorde suos in Hebr. 6:4.8; 10:26-31; 12:17-29. Hiér geld dit, dat wie so teen die Heilige Gees gelaster het, geen vergifnis tot in ewigheid het nie, maar skuldig is aan die ewige sonde, Mark. 3:29.

(ii) Matt. $12: 32$; Luk. $12: 10$.

Ons kom nou tot die tweede van hierdie voorstellings in die Sinoptiese Evangelies soos dit uitgespreek word in Matt. $12: 32$ en Luk. $12: 10$.

Waar die uitsprake in Mark. 3:28,29 en Matt. 12:31 die historiese

4) Vgl. S. P. J. J. van Rensburg, Hagios in die Nien-Testamentieste Voorstelling, Proefskrif 1958, bl. $171 \mathrm{vv.}$ 
grondslag van Jesus se wourde verteenwoordig en in historiese verband gebring word met die lastering van die Fariscërs as gevolg van Jesus se uitdrywing van die demone, daar het ons in Matt. $12: 32$ en Luk. 12:10 geen historiese omraming vir die tweede voorstelling nie. Hier word eenvoudig 'n spreek teen die Scun van die mens gestel teenoor 'n spreek of lastering teen die Heilige Gees, en dan sê Jesus dat elkcen wat in woord spreek teen die Seun van die mens, dit sal hom vergewe word, maar elkeen wat spreek (of gelaster het -- Luk. $12: 10$ ) teen die Heilige Gees, dit sal hom nie vergewe word nie, in hierdic ecu nie, en ook nie in die tockomende nie, vgl. Matt. 12:32.

Daar is egter nóg 'n belangrike verskil tussen die twee voorstellings. In dic uitspraak oor die lastering tcen die Heilige Gees soos vertcenwoordig in Mark. 3:28, en Matt. 12:31 het ons die voorstelling van die Heilige Gces as die Gees warmee Jesus by sy doop en tydens sy aardse bestaan as Mcssias toegerus was om die ryk van die duisternis te verstoor en die eskatologiese Godsryk te bring. Maar die uitsprake van Luk. 12:10 en Matt. 12:32 is gespreek van uit die gesigspunt van die Pinkstergemeente. Dit verteenwoordig die voorstelling van die Heilige Gees as Pinkstergecs. ${ }^{5}$ ). Hierdie uitsprake is dus gevul met Pinksterinhoud ${ }^{6}$ ). Want toc die Evangeliste geskryf het was Pinkster lankal verby, en kon hulle spreck vanuit die sekerheid dat die Heilige Gees aan die gemeente geskenk is en unmiskenbaar in die gmeente en in die gelowiges werksaam was. Van niks was die oudste gemeente meer onmiddelik bewus nie as van die lewende, werkende goddelike krag warmee die Heilige Gees aan die werk was is die gemeente en in hulle eie harte. En daarom interpreteer hulle die oorspronklike woord van Jesus vanuit die gesigspunt van die Pinkstergemeente. In beide Matt. 12:32 en Luk. 12:10 word Jesus ho huios ton anthrópon genoem teenoor to pneuma to hagios, en dan word gesê dat die spreek teen die Seun van die mens vergewe sal word, maar die lastering teen die Heilige Gees is onvergecflik. „De Scun van dic mens" sien hier op Jesus se aardse bestaan in die vlees. "). Toe was $\mathrm{Hy}$, soos Rom. $1: 3,4$ dit nuem, na sy aardse bestaan kata sarka, seun vas Dawid, en was $\mathrm{Hy}$ nog nie na die Heilige Gees ${ }^{8}$ ) met krag verklaar as

5) Vgl. Procksch in ThWb. I, $104 \mathrm{f}$. en W. Beyer in ThWb. I, 623, asook E. Schweitzer in ThWb. VI, $405 \mathrm{ff}$.

6) Vgl. Procksch in ThWb. I, 105.

7) Ons vind in die Sinoptiese Evangelies, maar veral by Matt. hierdie uitdrukking "Seun van die mens', as 'n indirekte selfaanduiding val. Jesus self. Die tekste waar Jesus aangedui word, as Seun van die mens" kan in drie groepe verdeel word: (a) die, wat sien op Jesus se aards" bestaan in die vlees; (b) die wat wys na die Seun van die mens wat moet ly en sterwe, en (c) die derde groep tekste wat die Seun van die mens beskrywe in sy verhoging, sy heerlikheid en wederkoms.

¿) Pneuma hagiósunés in Rom. 1:4 is 'n letterlike vertaling van ruag hak kodesh, en beteken pnendma hagion, vgl. H. Lietzmann, Der Brief an die Römer, ad loc. 
die Seus van God nie. In sy aardse bestaan was sy heerlikheid en godde. likheid nug verborge, en kon die sonde en lastering teen Hom as Seun van die mens nog onbewus en in onwetenheid begaan word, en daarom vergeeflik wees. Maar nou is die tye van onwetenheid verby, vgl. Hand. $3: 17$. Deur die Pinkstergebeure is Christus met krag deur die Heilige Gees verklaar as die Seun van God, Rom. $1: 3,4$. Nou is vergissing nie meer moontlik nie. ${ }^{9}$ ). Die Evangeliste Mattheus en Lukas spreek hier uit die volle sekerheid dat die Heilige Gees aan die gemeente geskenk is en dat $\mathrm{Hy}$ onmiskenbaar in die gemeente werkend teenwoordig is. Daarom is nou 'n spreek teen, en 'n laster van die Heilige Gees bewuste vyandskap teen God, dis 'n sondig teen die Gees met opgehewe hand, bewus en opsetlik. Wie die Heilige Gees so duidelik an die werk sien met wonders en tekens en kragte, en sig tog teen die onmiskenbare werking van die Heilige Gees versit, sondig nie uit vergissing nie, maar met opgehewe hand, bejad rámá, Num. 15:30, opsetlik, en begaan 'n onvergeeflike sonde. Hierdie opsetlike sondig met opgehewe hand vind ons ook in die Nuwe Testament terug in die woorde van Hebr. 10:26: hekousiós gar hamartanonton hémón. Ook hier is die lastering teen die Heilige Gees nie die uitspreek van 'n vloekformule teen die pneuma nie, maar die bewuste vyandige weerstand teen die Gees van God, die stel van eie sondige wil teen die duidelik.geopenbaarde wil van die Heilige Gees, die opwek van die ywer en toorn van die Heilige Gees, die Gees wat dit nie verdra.om moedswillig en opsetlik uitgetart en weerstaan tc word nie.

\section{b. Hebr. $6: 4 \cdot 6$.}

In die brief aan die Hebreërs ontmoet ons die onherroepelike sonde in die gestalte van 'n afgestompte afsydige onverskilligheid teenoor die groot rykdom en heerlikheid van Gods genadewerk, wat die mens eenmaal ervaar het toe hy gelowig geword het en gedoop is. Die skrywer van Hebreërs waarsku baie ernstig teen die gevaar van dreigende afval van die geloof, omdat die afval, as dit eers gekom het, finaal en unherroepelik is. Die kern van hierdie waarskuwing is ongeveer saamgevat in Hebr. 6:4-8 en 10:26-30. Hierdie twee perikope moet nou nader betrag word, en die gedagtegang van die skrywer ontleed word.

Is Hebr. 6:4-6 praat die skrywer oor die onherroepelike wat daar lî́ in die afval van die geloof van iemand wat eenmaal as gelowige en gedoopte gedeel het in die rykdom van Gods genade en al sy gawes, maar wat dan tog met minagting sy rug op God keer, en wat homself betref, die Seun van God weer kruisig en openlik tot skande makk, en daarmec sê dat dit alles vir hom van geen betekenis is nie, maar hom koud laat.

9) Vgl. E. Schweitzer, ThWb. VI, 394 ff. 


\title{
HERVORMIDE TEOLDGIESE STUDIES
}

\author{
vir die bevordering van die \\ Bybels - reformatoriese teologie \\ in Suid - Afrika.
}

19e Jaargang

1964

ONDER REDAKSIE VAN :

Prof. Dr. P. S. Dreyer,

Prof. Dr. B. J. Engelbrecht,

Prof. Dr. S. P. Engelbrecht,

Prof. Dr. E. S. Mulder,

Prof. Dr. A. D. Pont,

Prof. Dr. F. J. van Zyl,

Prof. Dr. S. P. J. J. van Rensburg

Dr. J. I. de Wet.

Uitgegee met ondersteuning van die Navorsings, en Publikasickomitce van dic Universiteit van Pretoria. 
Ds. S. J. Botha, Die Historiese Agtergrond van die Kerkwet van 1862 van die Ned. Hervormde Kerk in die Z.A.R.

Dr. J. I. de Wet, Die Werk van die Predikant

Dr. J. I. de Wet en prof. dr. A. D. Pont, Diè Vraekompleks

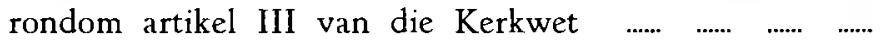

Prof. dr. B. J. Engelbrecht, Enkele Dogmatiese opmerkings oor

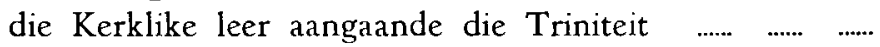

Prop. J. J. P. Müller, Die Voorleser in die Ned. Hervormde Kerk van Afrika

Ds. J. P. Oberholzer, Christusverkondiging en die Ou Testament

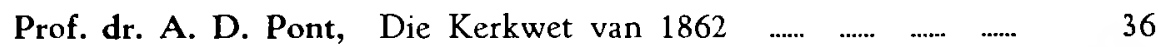

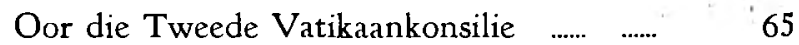

Prof. dr. F. J. van Zyl, Die Vrymesselary teologies beoordeel 47

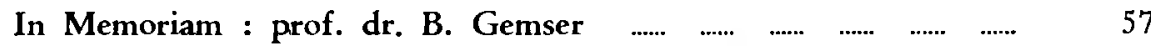

\section{BOEKBESPREKINGS}

Geloven op Maandag (F. J. van Zyl).

D. Bosch, Die Heidenmission in der Zukunftschau Jesu

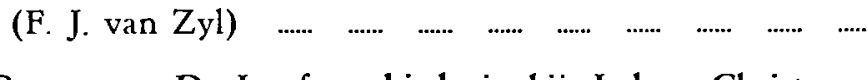

H. A. Brongers, De Jozefsgeschiedenis bij Joden, Christenen en Mohammedanen (J. P. Oberholzer)

G. P. van Itterzon en D. Nauta (red.) Geschiedenis van de Kerk (A. D. Pont)

J. N. Bakhuizen van den Brink. Protestantse Pleidooien uit de Zestiende Eeuw (A. D. Pont) …

A. G. Weiler e.a., Geschiedenis van de Kerk in Nederland

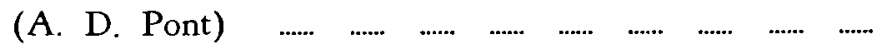

H. Pedin, Hrsg. Handbuch der Kirchengeschichte, Bd. I.

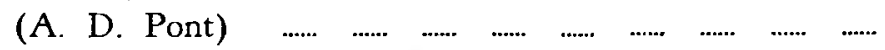

A. Heilmann, Texte der Kirchenväter (A. D. Pont) …......... 
In Hebr. 6:4v. noem die skrywer die genadegawes op waaraan dic gedoopte by sy doop deelgekry het. Die eerste wat hy noem is die verligting. Dit is die doop. Baie dikwels word in die ou kerk die woorde phótizein en photismos van die doop gebruik. En daarmee word bedoel dat by die doop die mens verlos is uit die mag van die duistcrnis, en oorgebring is in die ligryk van die Seun van God. Maar die doop is 'n eenmalige, onherhaalbare gebeurtenis. Die gedooptes word genvem hulle wat eenmaal verlig geword is, hapax photisthentes. Die doop is soos die sterwe van Christus ephapax, eenmalig, onherhaalbaar. Soos Christus eenmalig beslissend en onherhaalbaar gesterf het en begrawe is en opgestaan het vir die behoud van sondaars, so beeld die doop die werklikheid af da: die gedoopte in sy doop eenmalig en beslissend saam met Christus gesterf het, met Hom begrawe is deur die doop in die doud maar ook éenmalig met Hom opgestaan het tot die lewe in die nuwe Aeón. Die doop is die cenmalige onmisbare opname in die kerk as die liggaam van Christus. In die samehang met hierdie gedagtes van die doop as die eenmalige onherhaalbare gebeure in die lewe van die gedoopte is Hebr. 6:4.6 te verstaan. Want eigenlik wil die skrywer van Hebreërs hier nie sê dat die sondes wat na die doop begaan word, onvergeeflik is nie. Dit gaan hom om die beslissende eenmaligheid van die doop as opname in die gemeente en die deelkry aan al die heilsgoedere, _-..' 'n eenmaligheid wat, as dit deur die afval van die geloof en die uitval uit die gemeente, tot niet gemaak word, nie weer herhaal kan word nic.

Dis as gevolg van hierdie eenmaligheid van die doöp, en van die heils, gebcure wat daarin afgebeeld geword het, dat Hebr. 6:4v. sê dat dit on. moontlik is om dit wat eenmaal hapax, verlig geword het, d.i. éénmaal gedoop is en deel gekry het aan die Heilige Gees en al die heilsgoederc van die nuwe Aeón, - en dan afvallig geword het. weer tot bekering te vernuwe, d.i. weer tot berou en geloof te bring en weer te doop. Dis die dreigende gevaar van die sonde van die afval, waarmee Hebreërs besig is. Die afval van die geluof, - dit is vir die skrywer van die Hebreërs die sonde tot die dood toe, die onherroepelike sonde, want dit beteken om Christus opnuut te kruisig, om Hom openlik tot skande te maak, deur aan te sluit by hulle wat Christus verwerp het, en nog verwerp. Omdat die doop as opname in die gemeente eenmalig is, is die opname in die gemeente self ook eenmalig. Daarom heteken die sonde van die afval, dat die afvallige onherroepelik uitgesluit word uit die gemeente. Daarom is wederdoop ook ongeoorloof, en 'n verloëning van die wese van die doop. Netso is ook die afval finaal, want opname in die gemeente deur die doop kan nie weer herhaal word nie.

Dis tcen hierdie dreigende gevaar van die afval van dic geloof wat die skrywer die gemeente van Rome in die brief aan die Hebreërs waar sku. 
Wat wil die skrywer in Hebr. 6 vir die gemeente sê? Hy praat our die geestelike traagheid en agteruitgang in die gemeente. Dit was lankal tyd dat hulle tot geestelike volwassenheid moes kom. vgl. Hebr. 5:12vv. Hulle kan nie vir altyd stilstaan by elementêre leerstukke van die Chris. telike onderrig nie, maar hulle moet tot geestelike volwassenheid kom, Hebr. $6: 1 \mathrm{vv}$. Of dit vir die skrywer moontlik sal wees om met sy lesers tot die onderrig van hierdie diepere kennis van die waarheid te kom. hang tenslotte daarvan af, of God dit sal toelaat, Hebr. 6:3. Met hierdie woorde rig die skrywer sig tot die gewete van sy lesers. Met hierdie woorde: as Gud dit toelaat, wil hy sê dat dit gladnic so vanselfsprekend is, of God dit sal toelaat nie. Want hulle geestelike traagheid is 'n on. heilspellende teken dat hulle gevaar loop om an die geloof skipbreuk te ly (vgl. I Tim. 1:19), en van die geloof af te val. Hopelik is die geduld van God nog nie uitgeput nie. Miskien is dit nog nie te laat nie. Dit sal te laat wees as hulle eers die finale stap geneem het om af te val van die geloof, tenspyte van al die geestelike rykdomme wat hulle ontvang het. Want dié wat sig ná die volle ervaring van die heilsgoedere wat in die doop afgebeeld is, sig tog van die Christelike geloof afkeer, kan nie weer vir die geloof gewin word nie. Wat éénmal by die doop plaasgevind het, kan nie weer opnuut plasvind nie, Hebr. 6:6. By die doop het die gelowige ook die hemelse gawe gesmaak, d.i. die gawe van die sondevergifnis wat nou reeds vooruit gesmaak word. By die doop en toetrede tot die gemeente kry die gelowige ook deel aan die Heilige Gees, wat aan die gemeente geskenk is, - die Heilige Gees wat die lewende, kragtige werkende teenwoordigheid van God self in die gemeente is. Maar die Heilige Gees is ook dic Voleinder van die beloofde saligheid. Daarom word direk na die deelgenootskap aan die Heilige Gees ook genoem die ,goeie woord van God" en „die kragte van die toekomende eeu". Die goeie woord, die kalon réma is die kostelike beloftewoord waarmee ons toekomende erfnis beloof word. ${ }^{10}$ ). Die Heilige Gees wat die dopeling by sy doop ontvang het, is self die arrabón, die onderpand, die eerste paaiment. en dus die waarborg van ons hemelse erfenis. So smak die gelowige reeds die kragte van die teokomende eeu.

En nou sê Hebr. 6:4-8 dat die Christen wat dit alles ervaar hè, en dan tog tot die onmoontlike moontlikheid gekom het om sig van die geloof af te keer en afvallig te word, nie weer tot die bekering vernuwe kan word nie. 'n Christen wat al hierdie dinge ervaar het, maar sig tog van

10) In die Septuagint word kalon réma gebruik om dábár tób weer te gee, wat in Jos. $21: 45 ; 23: 15$ en Sag. 1:3 die betekenis het van die beloftewoord van God. Die, ,goeie woord", di. die belofte en die erfnis hoort vir Hebr. ten nouste 'saam, sodat in Hebr. 6:12, 17 gespreek word van die enfgename van die belofte, en in 9:15 van die belofte van die ewige erfenis. 
die Christelike geloof afgekeer het, is onherroepelik van die heil uitgesluit. Want 'n mens wat hom van so'n rykdom van genade afgekeer het, sê daarmee dat alles vir hum waardeloos is : sy doop waarmee $\mathrm{Hy}$ opgeneem is in die kerk, en beseël is as die eiendom van Christus, die hemelse gawe van die sondevergifnis, upgrond van die eenmalige en volkome offerande van Christus, die Heilige Gees wat ook die belofte en waarborg is van die toekomende hemelse erfenis. As dit alles vir hom verwerplik is en hy sy rug op hierdie dinge keer, deur van die geloof af te val, dan is daar niks verder aan te doen nie. 'n Ander en groter offer as Christus aan die kruis, kan en sal nie gebring word nie. Iets hoër en heerliker kan en sal vir hom nie aangebied word nie. Want waarmee sal hy nog aangelok kan word? Wat bly daar anders oor as die oordecl? Wie die ywer van God se liefdeheiligheid versmaad en afwys, sal te doen kry met die gloed en oordee! van sy ywerheiligheid wat brand in toorn. Hierdie oordeel word beskryf in 'n landbou-beeld : So'n goedversorge akkerland van God wat deel het aan al die sorg en seëninge, en wat dan tog dorings en distels oplewer, is naby die vervloeking, die einde daarvan is die verbranding, Hebr. 6:7,8. Christene wat afval van die geloof, en hulle self afkeer van die enigste Verlosser, en hulle enigste heil, is verlore.

Om hierdie perikoop wat met nadruk waarsku teen die gevaar van die onherstelbare afval van die geloof, reg te verstaan, muet in gedagte gehou word dat dit hier nie gaan om die doen van enkele groot sondes. soos bv. die sg. doodsondes van die Middeleeuse teologie nie. Dit gaan hicr nie om enkele bepaalde sondes nie, maar om die konsekwente afval en afkeer van die geloof, die algehele opgee van die geloof. Dic skrywer van Hebreërs sien hierdie guaar dreig, en waarsku cerdat dit sover gekom het. Want vir wie die geloof laat vaar het, het daar geen terugweg corgebly nie. Oor hierdie ,geen terugweg nie" merk H. Stratham op : ${ }^{11}$ ) „Aher nicht aus nur psychologischen Gründen, sondern aus theologischen. Die subjektive Unfähigkeit zur neuen Busse ist eine objektive Unmög. lichkeit derselben. In ihr vollzieht sich ein göttliches Gericht, vgl. Rom. 9". Subjektief lê die onmoontlikheid van terugkeer in berou en geloof, in die afgestompte onverskilligheid en apatie teenoor Christus en sy heil. ${ }^{12}$.) Objektief hierin dat wie volhardend sunder God wil wees, uiteindelik sonder God sal wees, en dit as 'n oordeel van God. So straf God sonde met sonde.... So is daar geen terugweg nie. Dis die bedoeling van die irrasionele werklikheid waarvan Rom. 1 spreek, en warin as antwoord van God op die volharding in die sonde, tot driemaal kom die woorde : „Daarom het God hulle oorgegee . . ." om te sondig. Rom. 1:24, 26, 28. Wie die genade en liefde van God minag en versmaad, en die geloof versaak, sal uiteindelik verval in 'n algehele verhar.

11) H. Strathmann, Der Brief aan die Hebräer, uit die Serie: Das Net? Testament Deutsch, Bd. 95, 104. 
ding in die sonde, in 'n afgestompte onverskilligheid. So wys die skrywer sy lesers op hierdie afgrond van die sonde, om hulle te watarsku teen die dreigende gevaar van afval van die geloof, eer dit geskied het, en dit te laat is. So lê die objektiewe onmoontlikheid van 'n terugweg ná 'n afval van die geloof ook in die beslissende eenmaligheid van die offer waardeur ons geheilig kan word, verder in die eenmaligheid van die doop as die onherhaalbare inlywing in die liggaam van Christus, maar ook in die eenmaligheid van die afval van geloof en die uitval van dic genade.

Dit het duidelik geword dat die skrywer hier nie handel oor mense wat bekommerd is oor hulle sondes nie en wat gekwel en gefolter word deur die angs en twyfel oor die vraag of hulle miskien die onvergeeflike sonde begaan het. Veeleer is hy besig met mense wat dreig om die prooi te word van afgestompte onverskilligheid en uiteindelik af te val van die geloof.

\section{c. Hebr. $10: 26-31$.}

Dieselfde waarskuwing van Hcbr. 6:4 -8 word in Hebr. 10:26-31 in soortgelyke woorde herhaal. Nadat die skrywer die lesers vermaan en bemoedig het, om in die geloof te volhard, om die belydenis van die hoop onwankelbaar vas te hou, Hebr. 10:19 vv. word die vermaning beklem:oon deur die ernstig wäarskuwing : Want as ons opsetlik sondig, nadat ons die kennis van die waarheid ontvang het, bly daar geen offer vir die sondes meer oor nie, maar 'n verskriklike verwagting van oordeel, en 'n vuurgloed wat die teëstanders sal verteer, Hebr. $10: 26 \mathrm{v}$. In die woorde „,bly daar geen offer vir die sondes meer oor nie", word die eenmaligheid en enigheid van die offer vir ons sondes beklemtoon. Vir wie hierdie enige offer verwerp, is daar nie 'n ander offer om sy sondes te versoen nie. Hierdie waarskuwing begin deur aan te sluit by die onderskeiding wat daar reeds in die Ou Testament gemakk is tussen die sonde wat in swakheid of dwaling bishegágá, Num. 15:26 begaan is, en waarvoor vergifnis moontlik is, en andersyds die sonde met opgehewe hand, bejảd rámá, Num. 15:30, 31 - die sonde wat dus opsetlik en moedswillig begaan is, en wat nie vergewe kan word nie maar met die dood gestraf moet word, Num. 15:30, 31. Hierdie opsetlike, moedswillige sonde word in Hebr. 10:26 beskryf met die woord hekousios. Dis 'n sonde wat die dood verdien, soos die wet van Moses voorskryf. Maar dis veel erger as die doodstraf; dis die toornglued van die heilige God, wat hier beskryf word as 'n verskriklike verwagting van oordeel, en 'n vuurgloed wat die teenstanders sal verteer. Dit is 'n veel ,swaarder straf" as die doodstraf volgens die wet van Moses. Want dis 'n verwerping van die enigste offer vir ons sondes, dis 'n vertrapping van die Seun van God, wat hom is Sy offerdood geheilig het. So iemand ag die bloed van die 
testament waardeur hy geheil is, koinon, onrein, profaan, soos gewone menshloed, - - hy smaad oormoedig die Gees van die genade. Hierdie oormoed van die mens, hierdie hybris, enhybrisas wek die toorn van God op.

Ook in Hehr. 10:26-29 gaan dit dus om die sonde van die afval van die geloof. Daarom sluit die warskuwing teen die op:etlike sonde an by die vermaning en bemoediging van Hehr. 10:23, nl. om aan die belydenis van die hoop onwankelbaar vas te hou, om vas te staan in die geloof. Die sonde van die afval is opsetlik, bejad rámá en daarom on. vergeeflik. Dis nie uit vergissing of dwaling begaan nie, want dis gedoen "nadat ons die kennis van die waarheid ontvang het". Dis onherroepclike sonde, want daar bly geen offer vir die sondes mecr oor vir hulle wat die bloed waardeur hulle geheilig is, onrein, profaan geag het nie. Daar om is dit die onherroepelike en onvergeeflike sonde. As die offer van Christus aan die kruis vertrap word, en daar geen ander offer meer oorbly nie, as die Heilige Gees, wat die Gees van die genade is, versmaad word, en so dic deur vir die genade gesluit word, as die mens sy rug keer op God en sy genade, en afval van die geloof, wat is daar anders te verwag as dic oordeel? Wie nie oorweldig word deur die ywergloed van Gods liefde nie, soos dit geopenbaar en geskenk is in die offer van Christus en die gawe van die Heilige Gees, sal te doen kry met die ruurgloed van sy ywerheiligheid wat soos 'n verterende vuur sal uithreek teen hulle wat die Seun van God vertrap en die Gees van die genade beledig; (vgl. Hebr. 10:31 : Vreeslik is dit om te val in die hande van die lewende God; Hebr. 12:29 : Want onse God is 'n verterende vuur", So word die werking van Gods ywerheiligheid in sy kontrasharmonie van genade en oordeel hier treffend beskrywe ${ }^{12}$ ) as 'n vermaning om die belydenis onwankelbaar vas te hou, maar ook as in waarskuwing teen die afval van die geloof as die onvergeeflike, onherrocpclike sonde.

\section{d. 1 Joh. 5 : 16.}

In I Joh. 5 : 16 beveel die apostel om voorbidding te doen vir 'n broeder wat ons sien sondig. Maar dan stel Johannes onmiddelik 'n beperking op hierdie voorbidding. Sy opdrag tot voorbidding geld alleen die broeder wat 'n sonde doen wat nie tot die dood is nie: Hiermee onderskei hy tussen 'n sonde wat tot die dood is, en 'n sonde wat nie tot die dood is nie. Wat hierdie sonde tot die dood is sê hy nie, maar stel tog vas dat dit ' $n$ sonde is wat die volle opheffing van die gemeenskap met God as gevolg het. Met hierdie onderskeiding sluit Johannes dus aan by die onderskeiding wat die Ou Testament reeds gemaak het tussen 'n sonde wat mens met vergissing begaan, en wat dus vergewe kan word, en

12) Vgl. Hebr. 6:4-8; 10:26-31; 12:16-29. 
'n sonde wat mens doen met opgehewe hand. 'n Sonde wat so opsetlik en moedswillig begaan is, kan nie vergewe word nie,maar moet met die dood gestraf word, Num. 15:30, 31. 'n Doodsonde is dus oorspronklik 'n skuld waarop die liggaamlike doodstraf gestaan het. As Johannes praat van die "sonde tot die dood", dan dink hy aan hierdie oorspronklike onderskeiding, hoewel Johannes daaronder die ewige dood bedoel. Vir niemand wat so'n sonde tot die dood toe hamartia pros thanaton begaan het, sê Johannes nie dat 'n mens moet bid nie, want dit sal betekenloos wees; so'n gebed vind geen verhoring nie. Ons kan nie met sekerheid vasstel wat Johannes bedoel het met die hamartia pros thanaton nie. Die waarskynlikste is dat Johannes dink aan die afval van die geloof, soos dit voorkom by dwaalleraars en by gemeentelede, wat deur hulle mislei is. Dit is ook die algemene strekking van die Johannesbriewe dat die sonde tot die dood die sonde van die afval is, vgl. I Joh. 2:18, 19, Joh. 13:30. 13).

Hierdie opvatting word ondersteun deur Holtzmann-Bauer " ${ }^{4}$ ) wat daarop wys dat in I Joh. $3: 14$ die kom tot die geloof beskryf word met die woorde: Metabebékamen ek tou thanatou eis tén zoén. Gevolglik kan 'n hamartanein pros thanaton beteken 'n terugval tot die oorspronklike onheil en ellende van die ongeloof, 'n afval van die geloof. Teenoor mekaar staan dan die twee uitdrukkings: eis tén zóén en pros tén thanaton. Volgens. Holtzman-Bauer is dus die sonde tot die dood die onherroepelike sonde, die afval van Christus af. En vir hierdie sonde is daar geen remedie en geen terugweg nie. Hierdie verklaring is ook in ooreenstemming met die algehele strekking van die hele Brief wat telkens waarsku teen die antichriste, en teen die verloëning van die Seun wat in die vlees gekom het, en dus ook die verloëning van die Vader beteken, vgl. I Joh. 2 : 18, 19.

In sy kommentaar op die Johannesbriewe sê Calvyn oor die „sonde tot die dood" in I Joh. $5: 16$, dat die sonde waarvoor daar geen hoop op vergifnis ourgebly het nie, hier ,die sonde tot die dood" genoem word. Hy sê verder dat mens uit die samehang mag aflei, dit nie soos hulle sê, 'n gedeeltelike val is, of 'n oortreding van 'n enkele gebod nie, maar die afval waardeur mense hulle geheel en al van God vervreem. As die Apostel hierna in I Joh. 5:18 byvoeg dat die kinders van God nie sondig nie, dan beteken dit dat hulle God nie heeltemal versaak en hulleself oorlewer aan Satan om sy slawe te wees nie. Calvyn twyfel nie daaraan nie dat hierdie sonde tot die dood toe, dieselfde is as die sonde en lastering teen die Heilige Gees.

13) Vgl. Johannes S.chneider, Die Kirchenbriefe, in N.T.D. 9. S. 184-186.

14) Vgl. Handkommentar zum Nenen Testament, Tubingen, 1908. Bd: IV, 2 Abteilung S. 359. 


\section{(4) Samevatting.}

Ons kan ten slotte enkele van die gevolgtrekkings wartoe ons gekom het, samevattend herhaal.

(a) Hierdie uitsprake wat handel oor die onvergeeflike sonde van lastering teen die Heilige Gees, our die sonde tot die dood toe, of die onherroepelike sonde van die afval van die Christelike geloof, waarop geen tweede bekering kan volg nie, - - lat ons die Heilige Gees sien as die heilige ywerende wil van God wat gehoorsaamheid vra en nie verdra om opsetlik weerstaan en uitgetart te word nic. Hierdie uitsprake laat ons die werking van die Heilige Gees sien in sy kontras-harmonie van oordeel en genade.

(b) Die lastering teen die Heilige Gees word nie begaan deur 'n cenmalige uitspreek van lasterlike woorde of van 'n vloekformule teen die Heilige Gees nie of deur die doen van sekere ernstige sondes nie. Marar dis 'n bewuste vyandige wecrstand teen die werk van die Heilige Gees, deur sy onmiskenbare werk toe te skryf an dic duiwel, en diarmee a.h.w. God self te sataniseer.

(c) Die sonde teen die Heilige Gees word nie begaan in onweten. heid, weens swakheid en dwaling nie. maar dit word gedoen met op. gchewe hand, opsetlik, hekousios: Dis 'n bewuste uittarting van God. Dis nie 'n sonde bishegágá, wat vergewe kan word nie. Volgens die Ou Testament het so iemand die Here versmaad, en moet hy onder sy volk uitgeroei word, Num. 15:30. Die gloed van hierdic ywerheiligheid hrand nog in die Nuwe Testament, vgl. Hebr. 10:31; 12:29.

(d) Dis nie soseer die begaan van bepaalde sondes nie, as 'n afval van die geloof en 'n verwerping van die volbragte genadewerk van God, 'n afval wat uitloup op 'n afgestompte onverskilligheid t.o.v. God en sy genadwerk, en 'n volkome apatie en onverskilligheid t.o.v. eie heil. So beskryf die brief aan die Hebreërs die onherroepelike sonde as die afval van dic geloof, wat uitloop op 'n onverskilligheid teenoor die groot rykdom van Gods genade wat die gedoopte tog cenmaal in al sy rykdom ervaar het, - 'n onverskilligheid wat uitloop op 'n algehele verharding. As hierdie afval gekom het, is dit onherroepelik, finaal; daarom waarsku Hebr. daarteen met groot erns. Hierdie onherroepelike van dic afval hang saam met die enigheid van die offer van Christus, (daar is geen ander offer meer oor nie) en met die beslissende eenmaligheid van die doop as die opname in die gemeent en die deelkry aan al die heilsgoedere, --- 'n eenmaligheid wat, as dit deur die afval van die geloof en die uitval uit die gemeente tot niet gemaak word, nie weer herhaal kan word nie. Daarom is dit onmoontlik om 'n gedoopte wat afvallig geword het. weer tot bekering te vernuwe, Hebr. 6:4vv. Omdat die doop as op. name in die gemeente cenmalig is, is die opname in die gemeente ook 
eenmalig, en daarom word die afvallige onherroepelik uitgesluit uit die gemeente. Die afval is finaal want die opname in die gemeente deur die doop kan nie weer herhaal word.

(e) As iemand bekommerd is oor sy sondes en gefolter word deur die angs dat hy miskien die onherroepelike en onvergeeflike sonde begaan het, dan is hierdie vrees en angs 'n onmiskenbare teken dat hy nog nie verval het in die toestand van bewuste vyandskap teen Gods Gees nie, in 'n afval van die geloof en 'n afgestompte onverskilligheid nie, en dus nie die onherroepelike en onvergeeflike sonde begaan het nie. Want wie bewus die werk van Gods Gees weerstaan, en dit duiwelswerk noem, wie van die geloof afval en so kom tot 'n toestand van volkome onverskilligheid, sal en kan daaroor nie meer beangs en bekommerd wees nie.

S. P. J. J. van Rensburg. 